\title{
First record of Pseudosuccinea columella (Say, 1817) from Salta province, northwest Argentina (Mollusca: Gastropoda: Lymnaeidae)
}

\author{
Dora Davies ${ }^{1 *}$, Lucía Nieva ${ }^{1}$, Lorena Ailán Choke ${ }^{1}$, Federico Soria Issa ${ }^{1}$, Julieta Pujadas ${ }^{2}$ and Lucila \\ Prepelitchi $^{2}$ \\ 1 Universidad Nacional de Salta, Facultad de Ciencias Naturales, Avda. Bolivia 5150, 4400, Salta, Argentina. \\ 2 Universidad de Buenos Aires, Facultad de Ciencias Exactas y Naturales, Instituto IEGEBA (CONICET-UBA), Departamento de Ecología, Genética y \\ Evolución, Ciudad Universitaria, C1428EGA, CABA, Argentina. \\ * Corresponding author. E-mail: dadaviesar@gmail.com
}

\begin{abstract}
Pseudosuccinea columella (Say, 1817) is a widely distributed freshwater snail of medical and veterinary interest because it is the first intermediate host of Fasciola hepatica (Linnaeus, 1758). It is an invasive species in the Neotropical region and in Argentina is known from the central and the northeast regions. Pseudosuccinea columella is reported for the first time from Salta province, northwest Argentina. This new record, the westernmost in Argentina, suggests that $P$. columella continues to increase its geographic distribution in the Neotropical region. Although $P$. columella is naturally infected with $F$. hepatica in northeast Argentina, snails from the new location in Salta province were not found to be infected.
\end{abstract}

DOI: $10.15560 / 10.3 .597$

Pseudosuccinea columella (Say, 1817) is a widely distributed freshwater lymnaeid snail (Madsen and Frandsen 1989). Its role in the transmission of Fasciola hepatica (Linnaeus, 1758), the causative agent of fasciolosis, has been demonstrated in several countries of South America (Prepelitchi et al. 2003; Coelho et al. 2003) and Oceania (Boray et al. 1984). Pseudosuccinea columella was first described in the US (Say 1817), from where it has spread into every South American country (Paraense 1982) except Chile and Bolivia. In Argentina, P. columella was restricted to the northeastern provinces of Misiones (Castellanos and Landoni 1981), Corrientes (Prepelitchi et al. 2003) and Entre Ríos (Paraense 1982), and the central provinces of Buenos Aires (Martín and Ovando 2013), Santa Fe (Rumi et al. 2008) and Córdoba (Zarco et al. 2011) (Figure 1). Its role in the transmission of $F$. hepatica

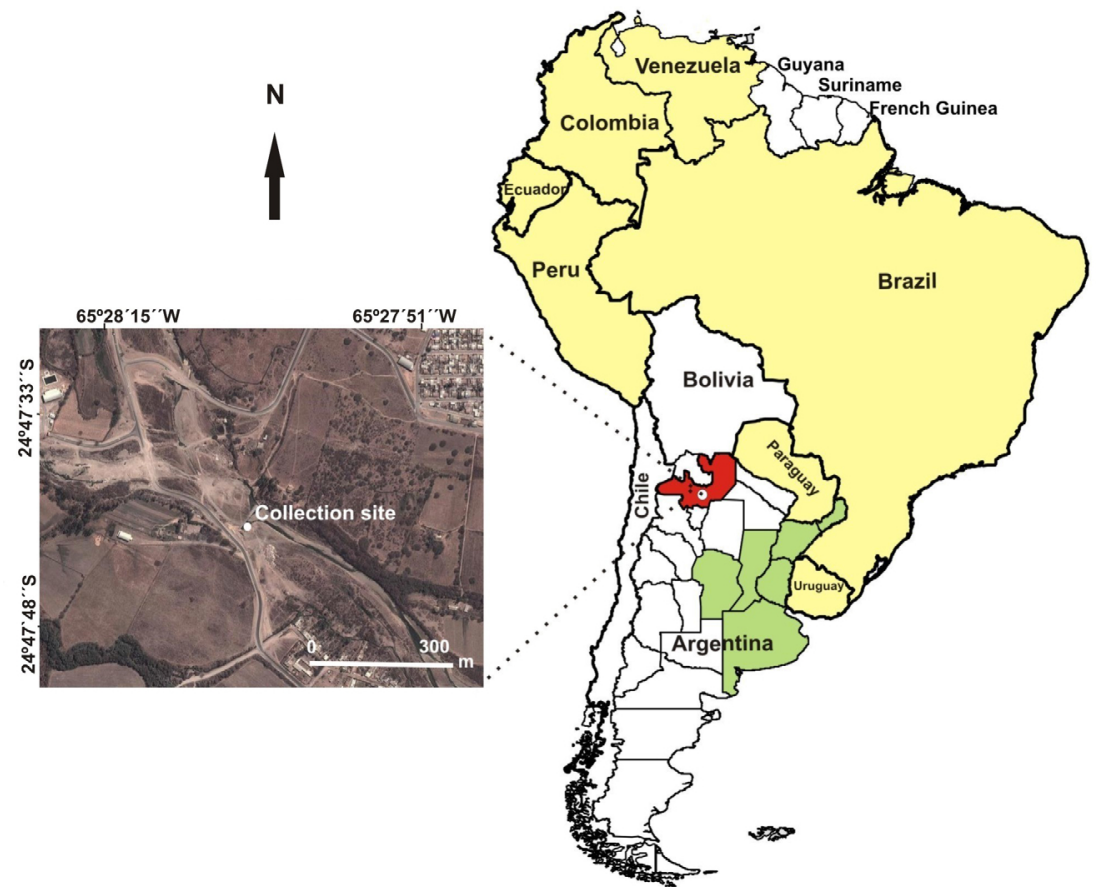

FIGURE 1. Geographical distribution of Pseudosuccinea columella in South American countries (in yellow) and in Argentinean provinces (in green), including the new record in Salta province (in red). Satellite image shows the location of collection site within Salta province, Argentina. Source: Google Earth. 
was only confirmed in Corrientes province (Prepelitchi et al. 2003). The objective of this work is to report for the first time the presence of $P$. columella in Salta province, northwest Argentina.

Snail sampling was carried out at Tres Palmeras, AriasArenales River $\left(24^{\circ} 47^{\prime} 41.03^{\prime \prime} \mathrm{S}, 6^{\circ} 28^{\prime} 04.18^{\prime \prime} \mathrm{W}\right)$ in the upper basin of Juramento River (Figure 1) at $1100 \mathrm{~m}$ a.s.l. (above sea level). This area is located in the Lerma Valley at the centre of Salta province and is characterized by a serrano-subtropical climate with a dry season (Bianchi and Yáñez 1981). Mean annual air temperature is $15.7^{\circ} \mathrm{C}$ and annual precipitation ranges between 500 and 700 $\mathrm{mm}$.

The study site was recently modified by the construction of a $5 \mathrm{~m}$ high wall, which forms a pool and a cascade (Figure 2). Specimens were collected at two separate times in April and May, 2013. Small gastropods were collected from plants and rocks by hand for 30 minutes, and kept alive in plastic containers with wet cotton layers. In the laboratory, snails were maintained in dechlorinated water for a week while assessing the emergence of cercariae on a daily basis. Snails were relaxed, euthanized and preserved in Railliet-Henry solution according to Paraense (1983). Taxonomic determination was carried out by examining features of the shell and internal organs, including the radula and genital system (Paraense 1982).

Snails were measured from the apex to the anterior margin using a 0-150 $\mathrm{mm}$ digital caliper. Shell length (L) and width (W), last whorl length (LWL) and aperture length and width (AL and AW) were measured on the largest 25 specimens. The relative proportions $\mathrm{LWL} / \mathrm{L}$, $\mathrm{W} / \mathrm{L}$, and $\mathrm{AL} / \mathrm{L}$ were calculated, and all measurements are expressed in $\mathrm{mm}$. Gonads were examined for pre-cercariae larval stages.

Voucher specimens were deposited in the Invertebrates I collection at the Natural Sciences Faculty, Salta National University (UNSa-FCN-I \# 0551-552) and in the Colección de Invertebrados del Museo Argentino de Ciencias Naturales "Bernardino Rivadavia" Buenos Aires (MACN-In \# 39.454).

A total of 98 specimens of Pseudosuccinea columella were collected and found to share their habitat with a population of Physa sp. Pseudosuccinea columella shells are oval in shape, had a short spire with a pointed apex, a

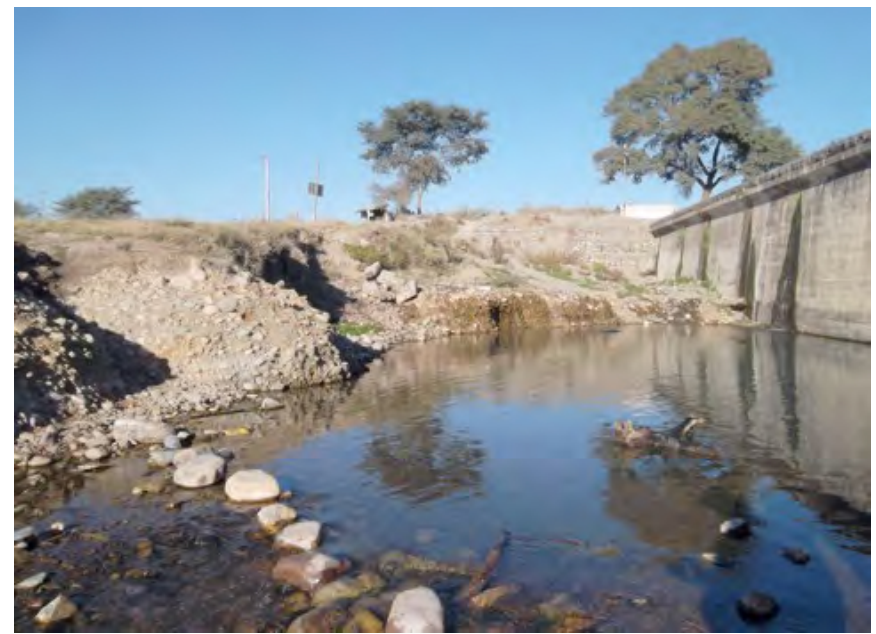

Figure 2. Collection site of Pseudosuccinea columella in Tres Palmeras, Salta province, Argentina $\left(24^{\circ} 47^{\prime} 41.03^{\prime \prime} \mathrm{S}, 65^{\circ} 28^{\prime} 04.18^{\prime \prime} \mathrm{W}\right)$. Photo by Daniel Paredes. large and expanded body whorl occupying more than twothirds of the total shell length, and a periostracum with incised spiral lines that cut the growth striations (Figure 3 ). These characteristics are identical to the description made for P. columella by Castellanos and Landoni (1981) and Paraense (1983).

Shell lengths of $P$. columella specimens $(\mathrm{N}=98)$ ranged between 3.25 and $13.90 \mathrm{~mm}$ (mean: $8.63 \mathrm{~mm} \pm \mathrm{SD}$ : 2.29). Shell measurements and proportions obtained from the largest specimens are as follows: $\mathrm{L}=8.66-13.90$ (11.04 \pm 1.55$), W=3.96-6.95$ (5.63 \pm 0.79$), \quad L W L=6.49-$ $11.55(8.82 \pm 1.79), \mathrm{AL}=4.74-9.19(6.87 \pm 1.43), \mathrm{AW}=2.88-$ $6.41(4.69 \pm 1.97), \mathrm{LWL} / \mathrm{L}=0.62-0.93(0.79 \pm 0.09), \mathrm{W} / \mathrm{L}=$ $0.39-0.66(0.51 \pm 0.07)$ and $\mathrm{AL} / \mathrm{L}=0.49-0.73(0.62 \pm 0.07)$.

The radula was rectangular, with a central row of small teeth, and lateral and marginal teeth as described by Castellanos and Landoni (1981) and Paraense (1983). The prostate was small and tubular, thread-like or ribbonlike in shape, and indistinguishable from the vas deferens. The penis sheath length to preputium length ratio was $1: 3$ to $1: 6$. The anatomy of the reproductive system concurs with the characteristics described for animals from Argentina (Castellanos and Landoni 1981) and Brazil (Paraense 1983).

None of the observed specimens was parasitized by Fasciola hepatica or other digeneans.

Fasciolosis is a sanitary problem in human populations in Andean countries of South America (Mas-Coma et al. 1999). In Argentina, human fasciolosis is underestimated due to a lack of medical records (Rubel et al. 2005). However, at a veterinary level, fasciolosis constitutes the fourth more important parasitosis for livestock production all over the country (Olaechea 2007). Fasciolosis transmission shows a patchy distribution directly associated with local dispersion of intermediate snail hosts (Mas-Coma et al. 1999). Therefore, the discovery of this new population of $P$. columella in Salta province could contribute to the spread of fasciolosis, given that this site is frequently visited by cows, goats and sheep that could potentially represent definitive hosts of $F$. hepatica. In adittion, the poor sanitary conditions, especially the discharge of sewage from nearby townships, further complicate the situation.

In Argentina $P$. columella was previously recorded at altitudes ranging from $21 \mathrm{~m}$ a.s.l. in Entre Ríos province (Paraense 1982) to $500 \mathrm{~m}$ a.s.l. in Córdoba province (Zarco et al. 2011). The new population detected in Salta province widens the altitudinal distribution range in Argentina to $1100 \mathrm{~m}$ a.s.l. It has been demonstrated that P. columella can survive and even transmit $F$. hepatica at $4500 \mathrm{~m}$ a.s.l. (Londoñe et al. 2009), because snails with a prevalence of $36 \%$ of parasite infection were found in Cusco, Peru. The risk of expansion of $P$. columella to Bolivia, favored by natural migrations or anthropogenic factors, is increased by the presence of snail populations in Argentina and Peru. This is the first report of Pseudosuccinea columella in Salta province, being the westernmost and highest location (1100 m a.s.l.) for this species in Argentina. Although we found no evidence of snail infection by $F$. hepatica in our samples, further studies are needed to evaluate the role of $P$. columella as intermediate host of $F$. hepatica in the area. 


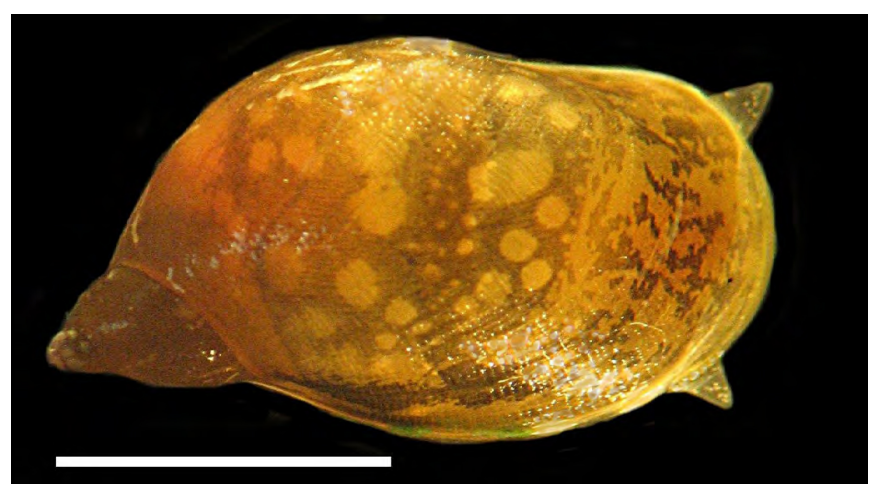

Figure 3. Dorsal view of Pseudosuccinea columella from Tres Palmeras, Salta province, Argentina. Scale bar: $5 \mathrm{~mm}$. Photo by Lucila Prepelitchi.

ACKNOWLEDGMENTS: This study was supported by grant \#1850 of the National University of Salta Research Council and by grant \#PICT 00031 of the Agencia Nacional de Promoción Científica y Tecnológica (ANPCYT).

\section{Literature Cited}

Bianchi, A. and C.E. Yáñez. 1992. Las Precipitaciones en el Noroeste Argentino. Salta: Instituto Nacional de Tecnología Agropecuaria, Estación Experimental Agropecuaria Salta. 384 pp.

Boray, J.C., G.C. Fraser, J.D. Williams, and J.M. Wilson. 1984. The occurrence of the snail Lymnaea columella on grazing areas in New South Wales and studies on its susceptibility to Fasciola hepatica. Australian Veterinary Journal 62(1): 4-6 (doi: 10.1111/j.1751-0813.1985. tb06030.x).

Castellanos, Z.A. de and N.A. Landoni. 1981. La familia Lymnaeidae Rafinesque, 1815 en la Argentina; pp. 55-82, in: Ringuelet, R.A. (ed.). Fauna de Agua Dulce de la República Argentina 15(5).

Coelho, L.H.L. and W.S. Lima. 2003. Population dynamics of Lymnaea columella and its natural infection by Fasciola hepatica in the State of Minas Gerais, Brazil. Journal of Helminthology 77(1): 7-10 (doi: 10.1079/JOH2002138).

Londoñe B., P., A. Chávez V., O. Li E., F. Suárez A. and D. Pezo C. 2009. Presence of Lymnaeidae snails with larvae of $F$. hepatica in altitudes over $4000 \mathrm{~m}$ above sea level in the southern highlands of Perú. Revista de Investigaciones Veterinarias de Perú 20(1): 58-65 (http:// www.scielo.org.pe/scielo.php?script=sci_arttext \&pid=S160991172009000100010\&lng=es\&nrm=iso).

Mas-Coma, M.S., J.E. Esteban and M.D. Bargues. 1999. Epidemiolgy of human fascioliasis: a review and proposed new classification. Bulletin of World Health Organization 77(4): 340-346 (http://cdrwww.who. int/bulletin/archives/77(4)340.pdf).

Madsen, H. and F. Frandsen. The spread of freshwater snails including those of medical and veterinary importance. Acta Tropica 46(3): 139-146 (doi: 10.1016/0001-706X(89)90030-2).
Martín P.R. and X.M.C. Ovando. 2013. Presencia de Pseudosuccinea columella (Say, 1817) en el sudoeste bonaerense; p. 122, in: Libro de Resúmenes, Primer Congreso Argentino de Malacología. La Plata, Argentina: Asociación Argentina de Malacología (ASAM) (http:// www.malacoargentina.com.ar/images/stories/ICAM/Libro_ Resumenes_1_CAM_2013.pdf).

Olaechea, F. V. 2007. Fasciola hepatica. Trematodes y Cestodes; pp. 159168, in: V.H Suárez, F.V Olaechea, C.E Rossanigo and J. R. Romero (eds.). Enfermedades parasitarias de los ovinos y otros rumiantes roedores en el cono sur de América. Bariloche: Ediciones INTA (http:// inta.gob.ar/documentos/enfermedades-parasitarias-de-los-ovinosy-otros-rumiantes-roedores-en-el-cono-sur-de-america/).

Paraense, W.L. 1982. Lymnaea viatrix and Lymnaea columella in the Neotropical region: a distributional outline. Memorias Instituto Oswaldo Cruz 77(2): 181-188 (doi: 10.1590/S007402761982000200008).

Paraense, W.L. 1983. Lymnaea columella in northern Brazil. Memorias Instituto Oswaldo Cruz 78(4): 477-482 (doi: 10.1590/S007402761983000400011).

Prepelitchi, L., F. Kleiman, S.M. Pietrokovsky, R.A. Moriena, O. Racioppi, J. Alvarez and C. Wisnivesky-Colli. 2003. First report of Lymnaea columella Say, 1817 (Pulmonata: Lymnaeidae) naturally infected with Fasciola hepatica (Linnaeus, 1758) (Trematoda: Digenea) in Argentina. Memorias Instituto Oswaldo Cruz 98(7): 889-891 (doi: 10.1590/S0074-02762003000700005).

Rubel, D., L. Prepelitchi, F. Kleiman, S. Carnevale and C. Wisnivesky-Colli. 2005. Estudio del foco en un caso de fasciolosis humana en Neuquén. Medicina (Buenos Aires) 65(3): 207-212 (http://www.scielo.org.ar/ scielo.php?script=sci_arttext \&pid=S0025-76802005000300004\&ln $\mathrm{g}=\mathrm{es} \& \mathrm{nrm}=\mathrm{iso}>$ ).

Rumi, A., D.E. Gutiérrez Gregoric, V. Núñez and G.A. Darrigran. 2008. Malacología Latinoamericana. Moluscos de agua dulce de Argentina. Revista de Biología Tropical 56(1):77-111 (http://www.redalyc.org/ articulo.oa?id=44918831006).

Say, T. 1817. Descriptions of seven species of American fresh water and land shells, not noticed in the systems. Journal of the Academy of Natural Sciences Philadelphia 1(2):13-16 (https://archive.org/ stream/cbarchive_47733_descriptionsofsevenspeciesofam 1817 / descriptionsofsevenspeciesofam1817_djvu.txt).

Zarco, A., M.C. Fantozzi and P.F. Cuervo. 2011. Gastropoda, Pulmonata, Lymnaeidae, Pseudosuccinea columella (Say, 1817): first record in Córdoba province, central Argentina. Check List 7(4): 391-393 (http:// www.checklist.org.br/getpdf?NGD120-10).

RECEIVED: January 2014

ACCEPTED: April 2014

Published ONLINE: July 2014

EDITORIAL RESPONSIBILITY: Robert Forsyth 